\title{
DEVELOPMENT OF DAIRY SECTOR RELATED AGRICULTURAL POLICIES IN THE EUROPEAN UNION, THE WAY TO THE 2013 CAP REFORM*
}

\author{
DESARROLLO DE POLÍTICAS AGROPECUARIAS \\ PARA EL SECTOR LECHERO EN LA UNIÓN \\ EUROPEA, LA VÍA A LA REFORMA PAC DE 2013
}

ILDIKó SZEGEDY-MASZÁK**

\begin{abstract}
PARA CITAR eSTE ARTículo / To CITE THIS ARTICle Szegedy-Maszák, I., Development of dairy sector related agricultural policies in the European Union, the way to the 2013 cap reform, 24 International Law, Revista Colombiana de Derecho Internacional, 83-111 (2014).
\end{abstract}

doi:10.11144/Javeriana.IL14-24.ddsa

* Artículo producto del proyecto de investigación El derecho económico en Colombia y sus relaciones con las directrices y recomendaciones de las instituciones públicas de derecho económico transnacional, ID Proyecto: 00005131 de la Facultad de Ciencias Jurídicas, Pontificia Universidad Javeriana. El texto se finalizó con fecha 31 de octubre de 2013.

** Ph.D en Sociología Jurídica e Instituciones Políticas, Universidad Externado de Colombia. LLM (Magíster) en Derecho de Negocios Internacionales, London School of Economics and Political Science. Abogada ELTE ÁJK Budapest. Profesora investigadora Departamento de Derecho Económico, Facultad de Ciencias Jurídicas, Pontificia Universidad Javeriana Bogotá. Email: ildiko@javeriana.edu.co 


\begin{abstract}
The present article discusses the dairy sector related issues of the Common Agricultural Policy (CAP) in the European Union, being, for this purpose, one of the most important agricultural sub-sectors. The historic development of CAP demonstrates its protectionist nature from its origins; although its recent reforms seem to recognize growing market orientation. The CAP has been influenced by changing policy paradigms, whereas multifunctionality prevails and result in the exceptional treatment of agriculture. Public policy actors exercise significant influence on the development of CAP. Therefore, the post-2013 CAP projections are analyzed considering the different interests of dairy sector stakeholders.
\end{abstract}

Keywords author: European Union, Common Agricultural Policies, dairy producers, agricultural public policies, public policy actors, policy paradigms.

Keywords plus: European Union, agriculture and state, dairy production, public policy. 


\section{RESUMEN}

En el presente artículo se discute la Politica Agrícola Común (PAC) de la Unión Europea aplicada al sector lácteo, uno de los subsectores más importantes en esta relación. El desarrollo histórico de la PAC demuestra que, desde sus orígenes, era una politica agropecuaria proteccionista, aunque sus recientes reformas tienden a reconocer una creciente orientación hacía el mercado. La PAC ha sido influenciada por cambiantes paradigmas políticas, donde la multifuncionalidad sigue siendo predominante y resulta en un trato excepcional de la agricultura. Los actores de políticas públicas tienen influencia significativa en estos desarrollos. Por esta razón, las proyecciones de la PAC después de 2013 se analizan bajo la consideración de los diferentes intereses de los actores del sector lácteo.

Palabras clave autora: Unión Europea, Política Agrícola Común, productores de leche, políticas públicas agropecuarias, actores de políticas públicas, paradigmas, políticas.

Palabras clave descriptores: Unión Europea, política agrícola, leche, producción, políticas públicas.

\section{SUMMARY}

Introduction. - i. Development of COMmon agricultural policy (CAP), PERIOD OF DIRECT PRICE SUPPORT (1962-1992). A. Origins of the CAP and Early Development of its Price Support System.- B. Price Support Schemes for the Dairy Sector C. MacSharry Reform. - II. 2003 CAP REFORM DECOUPLING OF AGRicultural SuPPORTS AND THE 2008 CAP HeAlth CHECK. $-A$. Fischler Reform.- B. Fischler Reform and the CAP Health Check in the Dairy Sector.- 1. Market Management Mechanisms.- 2. Producers' Income Enhancement Mechanisms.- 3. Rural Development Policies.- C. Adjustments in the EU Dairy Sector.-III. Considerations of POST-2013 CAP. - A. 2013 CAP Reform Proposals of the European Commission.- 1. Market Management Mechanisms.- 2. Direct Payments.- 3. Rural Development Policy Instruments.- B. Positions of Dairy Sector Stakeholders on 2013 CAP reform.- IV. CONCLUSION.- BIBLIOGRAPHY 
INTRODUCTION

The baseline regulation of the dairy sector in the Eu is the Common Agricultural Policy (as follows CAP). CAP was historically considered as one of the most trade distorting domestic agricultural support schemes in the World. This affirmation was true for its original price policy, which came into effect in 1967 and functioned with minor modifications until the MacSharry reforms in 1992. During these first 30 years, the CAP was based on production based domestic subsidies with artificially established price support accompanied by high import duties, export refunds and intervention stockholding. With the MacSharry ${ }^{1}$ (1992) and Fischler $^{2}$ (2003) reforms, production based subsidies were gradually replaced by decoupled direct payments to producers through the Single Farm Payment System. Rural development policies also gained more importance. Currently, the CAP has two Pillars: Pillar One is destined to finance market management and direct payments from Eu funds; Pillar Two is aimed to finance rural development policies based on a co-financing scheme between the EU and the Member States.

As a result of deep reforms, CAP is ready to face the future implementation of the 2008 wTO modalities ${ }^{3}$. Nonetheless, in the eu farmers still receive $30 \%$ of income subsidies, and market management policy tools keep using intervention stockholding and export refunds. Furthermore, as argued by Johan Swinnen CAP reforms did not reduce agricultural import duties ${ }^{4}$. Therefore, the challenge of the next CAP reform in 2013 (entering into

1 Ray MacSharry, European Commissioner for Agriculture and Rural Development, 1989-1993.

2 Franz Fischler, European Union's Commissioner for Agriculture, Rural Development and Fisheries, 1995-2004.

3 Burrell in The Common Agricultural Policy: Policy Dynamics in a Changing Context, 12 (G. Skogstad \& A. Verdun, Eds., Routledge, London \& New York, 2009).

4 J. Swinnen, Ed., The Perfect Storm: The Political Economy of the Fischler Reforms of the Common Agricultural Policy, 136 (Center for European Policy Studies, Brussels, 2009). 
force in 2014) is to implement policies, which result in even more market orientation.

This article analyses the CAP from a domestic support perspective, especially as related to the dairy sector. CAP domestic support is of major importance for Colombia as this public policy system makes one of the fundamental differences between Colombian and EU regulation of the dairy sector. This CAP study also describes the policy paradigm changes in its political, economic and social context ${ }^{5}$. For these purposes, the CAP is analyzed in three historic moments: i) period of direct price support (19671992); ii) decoupling of support payments with the 2003 CAP reform and the 2008 CAP Health Check; and iii) post-2013 CAP.

\section{DEVELOPMENT OF COMMON AGRICULTURAL POLICY (CAP), PERIOD OF DIRECT PRICE SUPPORT (1962-1992)}

Historically, trade protectionism was dominant in agriculture throughout Europe. Since the 1880s protectionist policies were implemented against overseas competitors; while in the two World Wars they were related to food shortages. The six original founders of the EEC faced similar challenges at the time of establishing the CAP: i) to increase production to guarantee food supplies; ii) to relieve balance of payments constraints already affected by protectionist agricultural policies; and iii) to increase farm incomes. The agricultural policy instruments followed by them were also similar: i) intervention prices ${ }^{6}$; ii) regulated imports and government buying; and iii) rural-based employment policies?

On the other hand, these policy instruments resulted in early food surpluses already in the late 1950s, especially in France,

\footnotetext{
5 Member State specific policies are not studied. Nevertheless, the positions of certain Member States are considered throughout the whole analysis.

6 Over $70 \%$ of agricultural production was supported by guaranteed prices in France, Germany, the Netherlands and Luxemburg, 39\% in Belgium and only $27 \%$ in Italy. R. Ackrill, The Common Agricultural Policy (Contemporary European Studies), 27 (T \& T Clark, London, 2000).

7 Óp. cit., pp. 26-27.
} 
despite the economic consequences of the Second World War. This way, the negotiations to form the European Economic Community (EEC) were tightly linked to the establishing of the CAP. Potential food exporting countries such as France were unlikely to open their markets to industrial goods without having the opportunity to place their agricultural production surplus on other Member States' markets ${ }^{8}$.

\section{A. Origins of the CAP and Early Development of its Price Support System}

The Treaty of Rome, by which the EEC was established in 1958, provided the legal bases of the Common Agricultural Policy. The objectives and special methods there included are still in force regarding the special treatment required for the sector on economic, political and social bases; such as food supply on reasonable prices, stable agricultural markets, and fair standard of living for agricultural communities. The CAP financing rules were set by Council Regulation No 25 of 1962, which established the European Agricultural Guidance and Guarantee Fund (EAGGF or FEOGA - french acronym). This emerging CAP had three economic fundaments: i) single market (free circulation of goods, common prices and stable exchange rates); ii) community preference (protection from lower prices within the EEC), and iii) financial solidarity (common system of revenues and outlays).

As argued by Robert Ackrill the original aim of the CAP was to increase trade in agricultural goods between Member States and with third countries, strengthening agricultural exports without subsidies, removing quotas on trade and avoiding production surpluses ${ }^{10}$. Yet, as the original CAP negotiations were rather difficult, because of differing interests between Member

\footnotetext{
8 The absence of the UK as founding Member State of the EEC was highly influenced by its position of rejecting the inclusion of foodstuffs in the negotiations, as it would have affected its trade relations in the Commonwealth. Ibidem, p. 29.

9 Ackrill, Óp. cit., p. 33.

10 Ibidem, p. 31.
} 
States ${ }^{11}$, the resulting CAP was based on the harmonization of the protectionist agricultural policy instruments already in place in the Member States in the 1950s. That way, support prices, levies on imports, intervention buying, and export refunds were the political compromise to achieve the CAP. The result was high CAP product prices (higher than pre-CAP level) ${ }^{12}$, and the loss of the original CAP aim to keep supply and demand in balance. Prices were finally agreed for products covered by the CAP by 1968 (and for wine in 1970); whereas the own resources of the EEC budget were established in $1970^{13}$.

\section{B. Price Support Schemes for the Dairy Sector}

Milk production was considered as "the basis of the farmer's income in the EEC"14. Milk and milk products had been heavily subsidized by CAP Member States since pre-CAP time. Therefore, the harmonization of these national policies resulted in a system based on high level of price support, justified by the necessities to protect milk farmers' livelihoods.

For milk and milk products the Common Market Organization (смо) started operating in 1964. The main objective of the CMO was to provide price support based on the ex-farm target price. The target price was set for each dairy product, based on the EEC region of highest consumption to balance price differences between the Member States. The target price was the price to be received by the producers on the open market. The target price system was accompanied by price support

11 Germany and Italy had higher agricultural product prices (especially for cereals) and were reluctant to negotiate lower prices; while France was opposing a common European budget financed from own EEC resources such as customs tariffs. Ibíd., p. 42.

12 Ackrill, Óp.cit.

13 The own resources of the EEC budget were: levies on agriculture, customs duties on trade (phasing-in by 1975), 1\% of a common EEC VAT (value-added tax) (phasing-in by 1979). Ibídem, p. 42.

14 Directorate General [DG] for Agriculture and Rural Development. Evaluation of CAP measures applied to the dairy sector, 89, available at http://ec.europa.eu/agriculture/eval/ reports/dairy/fulltext_en.pdf (November, 2011). 
mechanisms such as variable import levies, intervention buying and export subsidies.

From the target price a threshold price was calculated. The threshold price was the lowest import price plus a variable levy. The variable levy functioned as a tax to raise import prices when world prices fell to make imports as expensive as target price. That way, EEC domestic agricultural product prices, including milk and milk product prices were insulated from the world market. The Council established every year the intervention prices. Intervention buying took place when prices on the market fell below intervention price levels. The national intervention authorities stored these surpluses and placed them back on market when prices recovered ${ }^{15}$.

Already when the CMO for milk was established in 1964, the six EEC Member States had a joint annual milk surplus of about 1.7 million tons ${ }^{16}$. Despite of growing production surpluses, CAP prices for milk steadily rose between 1974 and 1976 by $40 \%$. Butter and SMP surpluses from intervention were sold through subsidized exports on the world market. The export price support was also financed from the CAP budget.

By 1977 the major CAP concern was the expenditure on the dairy sector, which used $40 \%$ of all guarantee spending (intervention and export subsidies) and $35 \%$ of total EEC budget ${ }^{17}$. Hence, the dairy sector was the first CAP sector where major restrictions were implemented in the form of a co-responsibility levy to stop milk and milk product surpluses and to control budgetary spending $^{18}$. Nevertheless, as prices were further rising, this measure had no important impact on production ${ }^{19}$. Notwithstanding, at that time, there was still not enough political will to implement real CAP reforms to control supply and budgetary spending,

15 Intervention buying was designed to mitigate seasonal fluctuations. On the other hand, it was not an appropriate policy tool to resolve structural problems or medium term price volatility. DG Agriculture and Rural Development. Óp. cit., p. 89.

16 Ibídem.

17 Ackrill, Óp. cit., p. 54

18 The co-responsibility levy was imposed on milk producers, and equaled to about $3 \%$ of the target price. Ibidem, p. 54.

19 Ibid. 
which required important reduction in price levels. Therefore, interim supply control solutions were implemented: guarantee thresholds in 1982, and a more radical policy tool in the form of production quotas (milk quotas) in 1984. The returning political argument against a deep reform was the necessity to protect the interests of small farmers and disadvantaged rural regions ${ }^{20}$. Traditionally, CAP was justified by the welfare argument to protect farm income. Based on the welfare analysis, CAP was not merely a commercial agreement, but a community based social policy to provide income redistribution to farmers, creating an agricultural welfare state ${ }^{21}$. This welfarist policy paradigm, as analyzed by Ann-Christina Knudsen, is more than a simple political paradigm. It is a "myth", socially and politically deeply embedded in European thinking ${ }^{22}$.

\section{MacSharry Reform}

In political terms, the first 30 years of the CAP (from 1962 to 1992) could be described as constant struggle between Member States and the Commission to raise agricultural target prices justified by the necessities to balance farm income. Support price policies resulted in growing production surplus and became financially and fiscally unsustainable. Prices were raised by EEC Agricultural Ministers, who were representing their governments in the Council. These decisions reflected the political influence of rural area voters and organized farm groups ${ }^{23}$ exercising pressure on their governments in the Member States ${ }^{24}$. Support price policies were welcome by farmers but they resulted in growing concern for consumers, taxpayers and the international community. As support prices insulated domestic market from world prices,

20 Lynggaard \& Nedergaard in The Common Agricultural Policy: Policy Dynamics in a Changing Context, 8 (G. Skogstad \& A. Verdun, Eds., Routledge, London \& New York, 2009).

21 A. Knudsen, Farmers on Welfare: the Making of Europe's Common Agricultural Policy, 308 (Cornell University Press, Ithaca, 2009).

22 Óp. cit., p. 307

23 Farmers had a higher degree of unionization than industrial workers, Ibídem, p. 292.

24 Ibíd. 
consumers had to assume the costs of high community food prices. Additionally, excess production resulted in environmental damage, which became another priority interest for the society. As variable import levies and export subsidies highly distorted international trade of agricultural goods, the international community through the GATT also influenced the EEC to reconsider its agricultural policies.

As a consequence, in 1992 Commissioner Ray MacSharry introduced the first comprehensive reform of the CAP. The MacSharry reform was influenced by the double necessity to resolve CAP budgetary pressures and to generate an adequate position in the GATT talks. Both aims required substantial support price cuts $^{25}$. In 1992, an overall $29 \%$ target price cut was introduced for arable crops, beef and sheep. These support price cuts were compensated by direct payments A set-aside scheme was also introduced to reduce over-supply. Therefore, the MacSharry reform resulted in a 30\% shift of funds from price support schemes to direct payments ${ }^{26}$. This shift of funds transferred part of CAP financing burden from consumers to taxpayers, although it did not reduce agricultural support levels ${ }^{27}$. Furthermore, the MacSharry reform formally established rural development policy as the second Pillar of the $\mathrm{CAP}^{28}$. Rural development policies included: agri-environmental and afforestation measures; as well as an early retirement scheme, which were co-financed by the EEC and the Member States ${ }^{29}$.

The political debate of the MacSharry reform in the Council was very strong and part of the reform proposal was sacrificed, especially modulation of direct payments. The original proposal wanted to limit the size of eligible land for direct payments, which

25 Ackrill, Óp. cit., p. 66.

26 Direct payments were recognized as a Blue box measure in the GATT/wTo Agreement on Agriculture, while rural development payments were considered as a green box measure. Moehler in Swinnen, Óp. cit., p. 81.

27 Lynggaard \& Nedergaard in Skogstad \& Verdun, Óp. cit., p. 38

28 Pillar 2 of the CAP was already foreseen in 1962, when one third of the EAGGF funds were destined to structural policies. Knudsen, Óp. cit., pp. 282-285.

29 Burrell in G. Skogstad \& A. Verdun, Ibídem, p. 8. 
would have favored small farmers ${ }^{30}$. As an additional political compromise to mitigate Italian opposition, the dairy sector was not included in direct payments; and only the Fischler reform implemented this new system in the dairy sector ${ }^{31}$.

It was publically recognized in the 1990s that former price support policies ${ }^{32}$ could not provide differential treatment to small farmers; and favored large farms with increasing production (representing only $20 \%$ of community farmers and receiving $80 \%$ of price support payments). The direct payment system implemented by the MacSharry reform was the first income support mechanism introduced into the CAP. Nonetheless, the MacSharry reform's direct payment system did not mitigate the situation of small farmers; most probably, because payments were established based on production data, without modulation or capping of these payments, which favored large scale farms ${ }^{33}$. By the end of the 1990 s, still only $7 \%$ of farms received $50 \%$ of CAP subsidies ${ }^{34}$. Therefore, one of the remaining core problems of the CAP was how to redistribute income in a way to fulfill its original major policy goal to provide welfare to community farmers.

From the 1990s onwards, additional considerations gained importance in the CAP; such as agri-environmental protection, food safety and quality, animal welfare, agricultural trade liberalization, and international competitiveness ${ }^{35}$. These new objectives reflected the influence of changing preferences in the

30 MacSharry was considered to especially favor small farmers, coming himself from a small farmer area of West of Ireland. A. Matthews, More on Capping Direct Payments. At http://capreform.eu/more-on-capping-direct-payments/ (October 6, 2007).

31 R. Ackrill, The Common Agricultural Policy (Contemporary European Studies), 66 (T \& T Clark, London, 2000).

32 It is worth recalling that until its 1992 reform, the CAP had no general policy mechanism to support farm income, other than by means of price policies.

33 It was also argued, that at the time of the MacSharry reform large farmers were more influential through their national lobbies on agriculture ministers in the Council than small farmers. Syrrakos in J. Swinnen, Óp. cit., p. 117.

34 A. Knudsen, Farmers on Welfare: The Making of Europe's Common Agricultural Policy, 273 (Cornell University Press, Ithaca, 2009).

35 The Commission was cautious not to accept the GATT talks as official motivation of the MacSharry reforms. On the other hand, by 2003 it was firmly institutionalized that farm income must be preserved in a less trade distorting way. Daugbjerg \& Swinbank in G. Skogstad \& A. Verdun, Óp. cit., pp. 50-51. 
society $^{36}$. The 2003 Fischler reform was based on a shift in policy paradigms towards multifunctionality, which reflected most of these new preferences. Furthermore, it prepared the way to achieve a more market oriented CAP.

\section{2003 CAP REFORM DECOUPLING OF AGRICULTURAL SUPPORTS AND THE 2008 CAP HEALTH CHECK}

The MacSharry reform established the bases for a radical move from production support towards income support. Nevertheless, the 2003 CAP reform, as also called the Fischler reform, was the most important modification of the CAP to this date. It dissociated price support from income support. The 2008 CAP Health Check, which was the last reform of the CAP to date implemented only minor changes to this system, and provided more flexibility to Member States through larger modulation of direct payments.

\section{A. Fischler Reform}

The Fischler reform was the result of the midterm review of Agenda $2000^{37}$. Fischler wanted to achieve the CAP reform before the opening of the 2007-2013 multiannual budget negotiations; as large CAP budgetary cut was in the pipeline ${ }^{38}$, because of falling support in the Commission and in the society regarding the $\mathrm{CAP}^{39}$. CAP had an unfavorable image of an over-expensive community policy, supporting major polluter European agriculture ${ }^{40}$.

Decoupling helped to promote the CAP as a policy instrument providing entrepreneurial freedom to the farmers but maintaining income support. The proposed modulation was to achieve

36 Burrell, Ibídem, p. 8.

37 Agenda 2000 was to provide financial stability to the EU including the CAP in view of the EU enlargement. Olper in Swinnen, Óp. cit., p. 83.

38 The perception of Fischler was that no significant CAP reform could be implemented, if the major consideration was the budget cut. Pirzio-Biroli in J. Swinnen, Ibidem, p. 105.

39 Pirzio-Biroli in J. Swinnen, Ibid. p. 102.

40 Pirzio-Biroli in J. Swinnen (Ed.), The Perfect Storm: The Political Economy of the Fischler Reforms of the Common Agricultural Policy, 103 (Center for European Policy Studies, Brussels, 2009). 
more social acceptability ${ }^{41}$. The idea of decoupling was so innovative that it helped Fischler to push through the CAP reform in the Commission, which was reluctant and wanted to see a $30 \%$ CAP budget cut ${ }^{42}$. In the Council: the UK, Germany, the Netherlands, Denmark and Sweden originally supported the Fischler reform; France, Spain, Portugal and Ireland were the major opponents (Lynggaard \& Nedergaard, 2009, p. 39) ${ }^{43}$. The price of the Fischler reform to be accepted by the Council was again the rejection to implement a maximum payment ceiling to direct payments ${ }^{44}$.

Fischler also strengthened the two new policy priorities: i) environmental protection and ii) food quality and safety aspects; yet managed to maintain the original welfarist idea of the CAP. It reflected the multifunctionality approach, which considered that farmers provided value added services to the society such as food supply and countryside protection, considered as common goods. Farmers were to be compensated for these services. Obligatory cross-compliance further justified this approach ${ }^{45}$.

The underlying negotiations of the Fischler reform not only reflected changing social priorities, but also modifications in political participation. Although Member State governments maintained bargaining power, they became more independent from national farmer lobbies ${ }^{46}$. Consumers, taxpayers and the food industry gradually converted into influential public policy

41 A. Knudsen, Farmers on Welfare: the Making of Europe's Common Agricultural Policy, 297 (Cornell University Press, Ithaca, 2009).

42 Pirzio-Biroli in J. Swinnen, Óp. cit., p. 105.

43 France was organizing a blocking minority in the Council and convinced Germany to support French position (the Germans owed a political favor to France for backing their decision not to participate in the Iraq war). Therefore, Fischler decided to request UK Prime Minister Tony Blair to negotiate with the Spanish government to change stand and ease the way to the Germans to vote in favor of the CAP reform, and that way unblock the French led minority (Lynggaard \& Nedergaard in Skogstad \& Verdun, Óp. cit., p. 106).

44 Original modulation proposal with a EUR 300,000 cap and degressivity was rejected in the Council (Knudsen, 2009, p. 297). The opposition of large scale farmers was especially strong in the UK, therefore, Prime Minister Tony Blair requested Fischler to drop capping from the proposal, in exchange to negotiate with Spain (see previous footnote). Pirzio-Biroli in Swinnen, Ibid., p. 107.

45 Knudsen, Óp. cit., p. 296.

46 Syrrakos in J. Swinnen Óp. cit., p. 118. 
actors ${ }^{47}$. Fischler considered these latter stakeholders as his main CAP reform allies ${ }^{48}$. As a result of the re-organization of major stakeholder groups, farmers lost their traditional exclusive participation in CAP policymaking ${ }^{49}$.

The Single Payment Scheme was the core element of the Fischler reform, through which the majority of direct payments were decoupled from production. Decoupled direct payments were linked to historical subsidy receipts. According to the $2008 \mathrm{CAP}$ Health Check, by year 2013, 92\% of direct payments were to be decoupled $^{50}$. Direct payments were considered as basic income support mechanisms for producers. Direct payments were conditioned to obligatory environmental requirements, and standards related to animal and plant health (cross-compliance) ${ }^{51}$. Modulation of direct payments became obligatory, which meant that from all farmers receiving more than EUR 5,000, a given amount of direct payment was redirected into rural development financing.

The 2008 CAP Health Check increased modulation to $10 \%$; and implemented a compulsory $4 \%$ cut of all direct payments above EUR 300,000 per receiver per year. Member States could use national envelop amounts (maximum 10\% of the national direct payment ceiling by sector) for purpose based Article 68 support, including environmental measures or improving the quality and marketing of products in the sector from which the corresponding amount was subtracted. The 2008 CAP Health Check lifted the restriction to apply Article 68 funds only in the sector of origin of the funds ${ }^{52}$. All the above was a move away

47 Burrell in Skogstad \& Verdun, Óp. cit., p. 10.

48 J. Swinnen, Ibídem, p. 145.

49 Syrrakos in J. Swinnen, Ibíd., p. 119.

50 DG Agriculture and Rural Development, p. 6 (2011b).

51 The set-aside scheme of the MacSharry reform was considered as a first intent to implement cross-compliance. On the other hand, the obligatory cross-compliance of the Fischler reform meant that farmers had to comply with value based policy demands of the Second Pillar of the CAP to receive full direct payment from the First Pillar. Knudsen, Óp. cit., p. 297.

52 DG Agriculture and Rural Development, p. 78 (2011a). 
from supply support towards more neutral income support, and also strengthened the environmental considerations of the CAP.

Producer price support was included within market management mechanisms. Market intervention became a last resort policy tool, which implemented a safety-net approach into CAP, an important change in priorities. Intervention prices still remained the central policy tool of market management. It provided certain income stability to farmers in front of market uncertainties $^{53}$. Currently, intervention prices are kept at low levels in the EU to bridge EU market prices with world market prices, which results in a decrease of EU food consumer prices but growing price volatility of production prices, this latter difficult to control.

Recent studies demonstrated that there would be no important decrease in production levels in the EU, if agricultural supports were totally abolished. On the other hand, it was also stated that the abolishing of agricultural subsidies would generate concentration of food production in the most competitive regions, which would result in unwanted social and environmental externalities. Therefore, agricultural support is the price of public goods provided by the sector including maintenance of living countryside and sustainable food production ${ }^{54}$.

Rural development policy was specially designed to encourage the provision of these public goods as well as to finance structural changes. Rural development policy was based on strategic objectives established at the Eu level and implemented through national programs. Its main policy areas were economic viability, the preserving of rural environment, and the support to the rural economy ${ }^{55}$. As shown above, after the Fischler reform and the 2008 CAP Health Check, modulation of direct payments provided further funds to rural development financing.

53 Market uncertainties in agriculture are the result of the reaction gap between demand signals and supply responses (inelasticity).

54 DG Agriculture and Rural Development, p. 7 (2011b).

55 It is required to spend at least $25 \%$ on improving environment, $10 \%$ on competitiveness, and $10 \%$ on quality of life. DG Agriculture and Rural Development, p. 9 (2011b). 


\section{B. Fischler Reform and the CAP Health Check in the Dairy Sector}

Support price cuts and the direct payment system were implemented in the dairy sector as part of the Agenda 2000 package and the Fischler reform. Intervention price cuts were first used in 2004. They were accompanied by production based dairy premiums to reduce the impact of intervention price cuts. Direct payments were converted into the Single Farm Payment Scheme in 2007. Furthermore, dairy quotas were expected to expire in 2015, resulting in an even more market oriented Eu dairy sector.

These changes were reflected in various public policy fields such as: i) market management; ii) producers' income enhancement; and iii) rural development; using a set of inter-related public policy measures. These public policy measures constitute the CAP regulation currently in force for the EU dairy sector.

\section{Market Management Mechanisms}

The most important market management mechanisms are the milk quotas, public intervention measures and export subsidies. The milk quota system is the key policy instrument of supply control in the dairy sector ${ }^{56}$. Currently, quotas are established annually for each Member State, based on historic milk production. With the CAP Health Check in 2008 a general 1\% per year quota increase was established in order to phase out milk quotas by $2015^{57}$. Currently, milk producers lobby for the maintenance of quotas, while milk processors request to carry on with its

56 Milk quotas, by country and producer, were implemented to regulate milk production surpluses in 1984. Reference quantities are assigned to each producer within the Member States. The overrun of the national quota results in the liability to pay a super-levy. Producers must contribute to the payment of this levy. Milk quotas can be transferred between farms by sale, lease or inheritance. DG Agriculture and Rural Development, pp. 72-73 (2011a).

57 According to the 2011 European Commission study, the net milk quota underuse in years 2009 and 2010 exceeded 10 million tons, equivalent to $7 \%$ of the total milk quotas, which allows the planned 2015 termination of the milk quota system. For the same period only Denmark, the Netherlands and Cypress overused its quota. DG Agriculture and Rural Development, pp. $72-73$ (2011a). 
abolition. Supply control is considered by milk producers as an appropriate policy measure to manage market price volatility, caused by the gradual reduction of support prices in the EU.

Buying into storage for butter and skimmed-milk powder (SMP) is the only public intervention measure available for the dairy sector. Intervention buying takes place at the guaranteed intervention price until the threshold limits are reached. As a result of the 2009 milk crisis, intervention buying was extended for 2009-2011, with the largest quantity of SMP going into storage in $2009^{58}$.

The purpose of the export subsidies is to bring high EU prices down to world market price levels. As a result of decreasing price supports in the EU and increasing world market prices, from 2006 export subsidized volumes and subsidy rates decreased, and export refunds were almost non-relevant in 2007 and 2008. The 2009 crisis of sharp decline in world dairy prices brought back to use export refunds, although with lower than pre-2004 rates $^{59}$.

\section{Producers' Income Enhancement Mechanisms}

The most important producers' income enhancement mechanisms implemented for the dairy sector are the direct payments. The CAP Health Check in 2008 resulted in full decoupling for the sector. As the dairy premium was established based on national milk quota allocated to a given farmer; the decoupled Single Farm Payment resulted from dividing the dairy premium by the number of hectares owned by the farmer and recognized in production by the Member State, or based on the herd number in case of dairy farmers without land.

58 Especially Germany and France participated in intervention buying; whereas smP public intervention stocks reached 250,000 tons in 2009 and 200,000 tons in 2010, compared to 0 level in 2007-2008. DG Agriculture and Rural Development, p. 77 (2011a).

59 Export refunds were important in 2009-2010 for cheese in the Netherlands, Germany, France and Finland, and for SMP in Belgium, France and Germany. DG Agriculture and Rural Development, p. 82 (2011a). 


\section{Rural Development Policies}

Rural development policies are relevant for the dairy sector as dairy farms have an important role in natural resource management. In most Member States dairy farms receive more rural development payment than non-dairy farms ${ }^{60}$. The new funding provided by the 2008 CAP Health Check can be used by the Member States specifically to accompany rural development measures in the dairy sector.

As a result of the milk crisis, a High Level Expert Group on Milk (HLG) was established by the Commission. The HLG recognized that the increasing concentration of the milk processing industry in contrast with dispersed milk producers, which distorts the balance in the supply chain. To address this issue, the "Milk Package" 61 regulated contractual relations and producer organizations. According to the Milk Package, written contracts between dairy farmers and dairy processors can be made compulsory by the Member States. These contracts must include: minimum duration, price, volume and collection clauses. The regulation also aims to strengthen the collective bargaining power of dairy farmers in the negotiations of supply contracts through producer organizations ${ }^{62}$.

\section{Adjustments in the EU Dairy Sector}

The implementation of the MacSharry-Fischler reforms and the 2008 CAP Health Check in the dairy sector were considered satisfactory by the Commission ${ }^{63}$. Enhanced market orientation was expected to result among others in lower milk producer prices and more competitive milk production.

After the CAP reforms milk producer prices had an initial downward trend, on the other hand, the food crisis and the milk

60 DG Agriculture and Rural Development, p. 85 (2011a).

61 At http://ec.europa.eu/agriculture/milk/index_en.htm (2011).

62 Agritrade (2012a).

63 DG Agriculture and Rural Development (2011a). 
crisis resulted in milk price fluctuations. It suggests that price stabilization policy measures (public intervention buying, public disposal schemes, and export refunds) were not able to handle the price boom in 2007-2008 and the price fall in 2009. As regards the price boom, they were not designed to manage situations when world market prices increased over the EU intervention price level. While in the 2009 milk crisis, the market intervention reaction turned out to be too slow. Price gap between Eu market prices and intervention prices was smaller than before, as a result of lower intervention price levels. Therefore, it required larger price decrease to trigger intervention measures, which allowed further deepening of the milk crisis ${ }^{64}$.

Furthermore, the effects of lower prices were compensated by increased subsidies (coupled and decoupled direct payments and national aids) ${ }^{65}$. It was also projected that average production costs would decrease in the EU, which would result in increasing EU competitiveness on the world dairy market. This appreciation was based on the expectations that lower prices result in efficiency improvements of low productivity farmers. Yet, this expected result could not have been observed for the 2003-2007 period $^{66}$.

Large cost differences remained among Member States, being the highest-cost producers in the EU -15 Finland, Sweden and Austria, and the lowest-cost producers in the same group Spain and Portugal; whereas production costs were more than double in Finland compared to Spain. The EU, especially Northern Europe maintains the highest milk production costs in the world with the same average levels as Canada. Compared to Oceania cost levels (average of New Zealand and Australia), which is the largest competitor of the EU, even lower cost EU countries such as Spain and the UK (closest to Us cost levels) still operate with almost the double of the Oceania costs ${ }^{67}$.

66 DG Agriculture and Rural Development, p. 191 (2011a).

67 Óp. cit., p. 209. 


\section{CONSIDERATIONS OF POST-2013 CAP}

The 2003 Fischler reform was supported by three major CAP policy paradigms: welfarism, multifunctionality and market orientation. Decoupling provided income support to farmers, reflecting welfarism. On the other hand, the low redistributive effect of the package was the major critic presented against the Fischler reform. It did not treat the uneven distribution of direct payments between Member States and between farmers.

As argued by Daugbjerg \& Swinbank multifunctionality justified CAP payments to compensate non-marketable positive outputs of the agricultural sector, such as maintenance of rural communities and environmental protection ${ }^{68}$. Cross-compliance and modulation was meant to support this paradigm. Notwithstanding, cross-compliance was questioned regarding its low environmental impacts. Modulation was also considered little effective to provide financing for rural development.

High price volatility was not properly managed after the food and milk crisis, and no positive changes were demonstrated in milk production competitiveness either. Decoupling reduced market intervention payments, which evidenced a major search for market orientation and resulted in a WTO conform CAP. Nevertheless, this reduction was compensated by (decoupled) direct payments. Moreover, the whole system was considered to have negative effects by maintaining the economic necessity to keep high trade tariffs ${ }^{69}$. This is the reason why, it was considered that the Fischler reform was still very far from the implementation of the trade liberal paradigm ${ }^{70}$. These findings established future regulatory necessities and became central issues in the current discussions about post-2013 CAP.

68 In Skogstad \& Verdun, Óp. cit., p. 54.

69 Olper in J. Swinnen, Op. cit., p. 99. There was debate regarding the importance of the wTO talks in the 2003 CAP reform. Some argued that it was the most important motivation. See also Daugbjerg \& Swinbank in Skogstad \& Verdun, Ibidem, p. 57. Others considered that it was only a political excuse of Fischler to win public support in favor of decoupling of direct payments. Syrrakos in Swinnen, Ibid., p. 127.

70 Daugbjerg \& Swinbank in Skogstad \& Verdun, Ibid., p. 55. 
The European Commission presented the 2014 CAP reform proposal to the European Parliament ${ }^{71}$ in October 2011. The new 2014 CAP has to be approved by both the Parliament and the Council ${ }^{72}$. A balanced CAP budget has primary importance in the overall $\mathrm{EU}$ financing, especially at the current unstable situation of the EU economies. Therefore, first time in the CAP's history, the EU negotiated the multiannual budget before the CAP reform ${ }^{73}$.

\section{A. 2013 CAP Reform Proposals of the European Commission}

The EC proposals for 2014 CAP reform ${ }^{74}$ were organized around the same three major policy areas established in the McSharry and Fischler reforms: (i) market management mechanisms; (ii) direct payments; and (iii) rural development policy instruments. The priorities of the 2014 CAP are: viable food production, sustainable management of natural resources, and balanced territorial development, whereas, the most important overall objectives are enhanced competitiveness, improved sustainability and greater effectiveness ${ }^{75}$.

\section{Market Management Mechanisms}

Market management mechanisms were designed to address market development goals accompanied by enhanced safety-net measures to strengthen competitiveness of individual producers. Market stabilization tools (intervention buying, aid for private storage, and export refunds) were proposed to be modified to be more efficient and more responsive in case of exceptional market conditions. Emergency measures were foreseen to treat

71 This is the first CAP reform, after the entry into force of the Lisbon Treaty, in which the European Parliament participates with equal legislative powers.

72 The final vote on the 2014 CAP in the EP Agriculture Committee is scheduled only after the 2014-2020 Eu budget is agreed.

73 Agritrade (2012b).

74 The description of the EC proposal is based on information extracted from DG Agriculture and Rural Development. At http://ec.europa.eu/agriculture/cap-post-2013/legal-proposals/index_en.htm (2011)

75 European Commission, 2011. 
general market disturbance situations financed from the new EUR 3.5 billion Crisis Reserve. To respond increasing price volatility, risk management tools were proposed to enhance extended cover of agricultural insurance schemes for revenue risks; including a compensation payment as well ${ }^{76}$.

\section{Direct Payments}

Direct payments were proposed to be divided between a basic payment amounting to $70 \%$ of the national budgetary envelopes; and supplementary payments for "greening" measures (environmental considerations) $(30 \%)^{77}$. As to basic payments, the EC proposal was to simplify cross-compliance requirements as well as to gradually level payment differences between Member States to result in a system of uniform payment per hectare by 2019 . The uniform payment scheme is one of the most controversial issues of the $2014 \mathrm{CAP}$, especially between the EU -15 (lobbying for longer phase in period) and the EU- 12 (lobbying for fast implementation). Basic payments received by any individual farm were proposed to be capped at EU 300,000 per year, and modulation was to be increased through degressive deductions. The proposals regarding greening of supplementary payments were also highly debated among stakeholders and did not count with the approval of the European Parliament either.

\section{Rural Development Policy Instruments}

Rural development policy instruments were included in the new Common Strategic Framework established by the Europe 2020 strategy ${ }^{78}$. To enhance performance, rural development financ-

76 Agritrade (2012b).

77 The European Commission proposed three "greening" measures: maintaining permanent pasture; crop diversification (cultivation of at least 3 crops, none accounting to more than $70 \%$ of the land, and the third at least on $5 \%$ of the land); and maintaining an "ecological focus area" of at least 7\% of farmland. Organic producers are considered per se in compliance with greening (European Commission, 2011).

78 Europe 2020 is the Eu's ten-year "smart, sustainable and inclusive" growth strategy, based on five key targets: employment, education, research and innovation, social in- 
ing is also target linked to six established priorities ${ }^{79} .5 \%$ of the funds is withheld in the Performance Reserve and is paid out only if target advances are achieved ${ }^{80}$.

There are major differences in the structure and development of the agricultural sector in the different Member States of the European Union. For this reason, there is a lack of consensus regarding post-2013 CAP. These differing interests will be translated most probably in a cautious reform. This reform will be based on the maintenance of traditional policy tools accompanied by a voluntary policy toolbox to provide sufficient leeway to attend differing necessities in the Member States, especially at new policy areas ${ }^{81}$, which can also result in a growing decentralization of CAP control at Member State level ${ }^{82}$.

\section{B. Positions of Dairy Sector Stakeholders on 2013 CAP Reform}

The positions of the dairy processors (EDA), dairy traders (EUCOLAIT) and consumers (BEUC) were the most market and free trade oriented. On the other hand, milk producers (EMB, COPA-COGECA, and ECVC) were more market intervention oriented, especially ECVC.

The CAP 2014 position of EDA, representing the dairy processors, was based on the affirmation that the success of the dairy processors is linked to the future success and competitiveness of European dairy farmers. For this reason, the CAP must remain adequately funded from Eu budget, with minimum national cofinancing. Therefore, modulation of funds between Pillar 1 and Pillar 2 should be moderated. EDA understood income support as

clusion and poverty reduction, and climatelenergy". European Commission, Europe 2020. At http://ec.europa.eu/europe2020/index_en.htm (2012).

79 The six priorities are: fostering knowledge transfer and innovation; enhancing competitiveness; promoting food chain organization and risk management; restoring, preserving and enhancing ecosystems; promoting resource efficiency and transition to a low-carbon economy; and promoting social inclusion, poverty reduction and economic development

80 Óp. cit. in rural areas. Agritrade (2012b).

81 Ibidem.

82 Burrell in Skogstad \& Verdun, Óp. cit., p. 16. 
a compensation for public goods provided by farmers. As regards direct payments, EDA did not favor shift towards flat rate payments and requested sufficient flexibility for the Member States. They preferred limited capping of direct payments. According to EDA, dairy quotas should be abolished and no additional supply control should be implemented ${ }^{83}$.

EUCOLAIT $^{84}$ represented dairy traders including wholesalers, exporters and importers. As large dairy processors were most frequently dairy traders themselves, EDA and EUCOLAIT positions were very similar regarding the CAP reform. EUCOLAIT also argued for a market oriented CAP and emphasized the importance of international trade of dairy products. EUCOLAIT opposed any form of milk supply control, considering as a harmful market intervention mechanism.

In complete opposition to the EDA and EUCOLAIT positions, the main concern of the European Milk Board (EMB) was the volatility of EU milk prices and the weak position of milk producers in the dairy supply chain. Therefore, the European Milk Board, representing the interest of milk producers, requested fair milk prices to be achieved by milk supply control to reduce the volume of milk, so that dairies could pay cost-covering milk prices. EMB rejected over supply and price dumping by export subsidies ${ }^{85}$.

COPA-COGECA favored redistribution of direct payments between Member States. As to flat rates they drew the attention to possible adverse effects and requested moderation in its implementation. They rejected capping of direct payments. Yet, they accepted maintaining coupled payments in certain sectors but drew the attention to possible competition distortions. Although

83 European Dairy Association, EDA Position on CAP Reform. At http://www.euromilk. org/upload/docs/EDA/EDA_CAP\%20Reform\%20Position_One-pager_February\%20 2012_final.pdf(2012a); and European Dairy Association, Briefing Paper on CAP Reform Autumn 2012. http://www.euromilk.org/upload/docs/EDA/EDA\%20CAP\%20Policy $\% 20$ Briefing\%20Autumn\%202012_final.pdf (2012b).

84 European Association of Dairy Trade, Eucolait Position on the CAP 2020 Proposals. At http://www.eucolait.be/positions-a-letters/14155-cap (2012).

85 European Milk Board, Dairy Farmers Demonstrate in Brussels: Milk Overflow Causing Prices to Plummet!. At http://www.europeanmilkboard.org/fileadmin/Dokumente/ Press_Release/Press_release_2012/EMB_Press_release_10.7.2012.pdf (2012). 
representing farmers, COPA-COGECA's position was closer to EDA's position (milk processors) than to EMB's position (milk producers) in most issues concerned ${ }^{86}$.

European Coordination Via Campesina (ECVC) represented the interests of small farmers and argued for strong market intervention. They criticized the European Commission's proposal and considered that it reflected the interests of industry, large retailers and international trade actors. As for direct payments, they rejected payment per hectare and proposed payment per active person. They supported capping direct payments but considered the proposed ceiling far too high. Considering market management they proposed supply control for all sectors to provide fair and stabilized prices. Therefore, ECVC opposed the suppression of dairy quotas. Although ECVC's position was more radical, it was similar in supply control aspects to EMB's requests ${ }^{87}$.

Consumers' opinion has growing importance in EU policymaking since the 1990s. As related to agriculture the consumers' priorities were: food security, health and safety, sustainability, quality, choice and affordability. BEUC, in representation of consumers, proposed a Common Food Policy instead of CAP, as a major change in policy approach. Consumers' priority was full compliance with safety standards to provide safe food based on transparent production. Thus, CAP should not promote products and sectors, it must be market oriented based on consumer choice. BEUC's position was rather different to the position of other corporate stakeholders ${ }^{88}$.

86 COPA-Cogeca, The Common Agricultural Policy after 2013. At http://www.copa-cogeca. be/Main.aspx?page=Papers (2012).

87 European Coordination Via Campesina, Legislative Proposals for the CAP 2014-2020: First Reaction of ECVC. At http://www.eurovia.org/spip.php?article508\&lang=fr (2011).

88 Bureau Européen des Unions de Consommateurs. BEUC's position on the EC Consultation on the reform of the CAP July, 2010. At http://www.beuc.eu/BEUCNoFrame/Docs/1/ IAPADBGBHMOMMDHNJOODEKEHPDWD9DBK219DW3571KM/BEUC/docs/ DLS/2010-00455-01-E.pdf (2010). 


\section{CONCLUSION}

As shown in this Article, the development of the CAP has been influenced by different policy paradigms over the last 50 years. The welfarist paradigm seems to maintain its influence during all these years. On the other hand, multifunctionality has gained force since the 1990s and complemented the welfarist paradigm. These two policy paradigms reflect the exceptional treatment of the agriculture in the economy. Exceptionalism is considered to be opposite of the trade liberal paradigm. Although since the 1990s there has been an important move towards a more market oriented CAP, even the post-2013 CAP reform is not expected to be led by the trade liberal principal. The discussions of this post-2013 CAP reform are still around welfarism and multifunctionality, whereas the major question is how to apply these two paradigms in a more market oriented way.

The proposals of a flat rate direct payment and capping of the same reflect the necessity to better redistribute income support payments. Conditioning 30\% of direct payments to enhanced cross-compliance, as well as the transfer of funds to Pillar 2 of the CAP to finance rural development are in accordance with a greener approach of the multifunctional paradigm. Enhanced risk management attends new problems of price volatility and reflect a mix of market intervention and market liberal principles. Although the single farm payment system was thought to disappear, it is not the case in the present reform. Furthermore, the food security discourse seems to strengthen its influence and justifies the continuation of subsidies in the future ${ }^{89}$.

Major dairy sector public policy actors are all in accordance with the necessity of agricultural market intervention. On the other hand, when supply control is discussed, dairy processors, traders and the consumers are fierce enemies of these control mechanisms. Notwithstanding, trade liberalism is still far to

89 Grant in J. Swinnen, The Perfect Storm: the Political Economy of the Fischler Reforms of the Common Agricultural Policy, 172-177 (Center for European Policy Studies, Brussels, 2009). 
gain support among CAP public policy actors in the dairy sector. The fact that the EU signs free trade agreements but maintains domestic support to the agricultural sector cannot be considered as a manifestation of trade liberalism. Nevertheless, as it was clearly demonstrated in the eu trade policies are integral part of agricultural sectoral policies and are subordinated to the necessities of internal policy developments. This approach is further supported by the fact that CAP is traditionally the result of policy debate with the participation of an ample array of policy actors traditionally present in CAP policymaking processes. 


\section{BIBLIOGRAPHY}

\section{Books}

Ackrill, R., The Common Agricultural Policy (Contemporary European Studies) (T \& T Clark, London, 2000).

Knudsen, A., Farmers on Welfare: the Making of Europe's Common Agricultural Policy (Cornell University Press, Ithaca, 2009).

Skogstad, G. \& Verdun, A., Eds., The Common Agricultural Policy: Policy Dynamics in a Changing Context (Routledge, London \& New York, 2009).

Swinnen, J., Ed., The Perfect Storm: the Political Economy of the Fischler Reforms of the Common Agricultural Policy (Center for European Policy Studies, Brussels, 2009).

\section{Digital Sources}

Agritrade. Executive Brief Update 2012: Dairy Sector. At http://agritrade.cta.int/ Agriculture/Commodities/Dairy/Executive-Brief-Update-2012-Dairy-sector (2012a).

Agritrade. Future CAP Fnancing for 2014-2020: Implications for the ACP (Executive Brief Update 2012) At http://agritrade.cta.int/Agriculture/Topics/CAPreform/Executive-Brief-Update-2012-CAP-reform (2012b).

Bureau Européen des Unions de Consommateurs. BEUC's position on the EC Consultation on the reform of the CAP July, 2010. At http://www.beuc.eu/ BEUCNoFrame/Docs/1/IAPADBGBHMOMMDHNJOODEKEHPDWD9DBK219DW3571KM/BEUC/docs/DLS/2010-00455-01-E.pdf (2010).

Copa-cogeca. The Common Agricultural Policy after 2013. At http://www.copacogeca.be/Main.aspx?page=Papers (2012).

Directorate Generale [DG] Agriculture and Rural Development. The CAP reform milk and milk products. At http://ec.europa.eu/agriculture/publi/fact/milk/ milk_en.pdf (1999).

DG Agriculture and Rural Development. Evaluation of CAP measures applied to the dairy sector. At http://ec.europa.eu/agriculture/eval/reports/dairy/fulltext_en.pdf(2011a).

DG Agriculture and Rural Development. Agricultural Policy Perspectives Briefs, Brief No 1 Rev. http://ec.europa.eu/agriculture/publi/app-briefs/01_en.pdf (January, 2011b).

European Association of Dairy Trade. Eucolait Position on the CAP 2020 Proposals A. At http://www.eucolait.be/positions-a-letters/14155-cap (2012).

European Commission. CAP Reform. An Explanation of the Main Elements. Reference: MEMO/11/685. At http://europa.eu/rapid/press-release_MEMO11-685_en.htm (2011). 
European Commission. Communication from the Commission to the Council, Dairy Market Situation 2009 \{Sec(2009) 1050\}. At http://eur-lex.europa.eu/ LexUriServ/LexUriServ.do?uri=COM:2009:0385:FIN:EN:PDF (2009).

European Commission. Europe 2020. At http://ec.europa.eu/europe2020/index_en.htm (2012).

European Coordination Via Campesina. Legislative Proposals for the CAP 2014-2020 : First Reaction of ECVC. At http://www.eurovia.org/spip. php?article508\&lang=fr (2011).

European Dairy Association. EDA Position on CAP Reform. At http://www. euromilk.org/upload/docs/EDA/EDA_CAP\%20Reform\%20Position_Onepager_February\%202012_final.pdf (2012a).

European Dairy Association. Briefing Paper on CAP Reform Autumn 2012. http:// www.euromilk.org/upload/docs/EDA/EDA\%20CAP\%20Policy $\% 20$ Briefing $\% 20$ Autumn $\% 202012$ final.pdf (2012b).

European Milk Board. Dairy Farmers Demonstrate in Brussels: Milk Overflow Causing Prices to Plummet! At http://www.europeanmilkboard.org/ fileadmin/Dokumente/Press_Release/Press_release_2012/EMB_Press_release_10.7.2012.pdf (2012).

Matthews, A., More on Capping Direct Payments. At http://capreform.eu/moreon-capping-direct-payments/ (October 6, 2007).

OECD. Agricultural Policy Monitoring and Evaluation 2012 oECD Countries. At http:// www.keepeek.com/Digital-Asset-Management/oecd/agriculture-and-food/ agricultural-policy-monitoring-and-evaluation-2012_agr_pol-2012-en (2012). 
